\title{
ORIGIN, STRUCTURAL AND TECTONIC HISTORY OF THE MACQUARIE ISLAND REGION
}

\author{
by P.E. Williamson
}

(with eleven text-figures)

WILLIAMSON, P.E., 1988 (viii): Origin, structural and tectonic history of the Macquarie Island region, Pap. Proc. R. Soc. Tasm., 122(I): 27-43. Papers presented at the Macquarie Island Symposium, Hobart, May 1987. https://doi.org/10.26749/rstpp.122.1.27 ISSN 0080-4703. Bureau of Mineral Resources, Canberra, A.CT., Australia.

Macquarie Island, in the Southern Ocean, was formed by oceanic crust uplift due to transpressive forces between the Indian/Australian and Pacific oceanic plates, in a transpressional regime which has persisted over the last $10 \mathrm{Ma}$. The amount of uplift is affected by regional isostatic compensation for crustal thickening; accompanying effects are tilting of rocks and rotation of the southern segment of the island. Gabbro and serpentinite, in the north, and basalts, in the south, all of which were formed in the primary oceanic crust, are now exposed. Consequently, magnetic properties of igneous rocks on the island correlate with similar features on the Indian plate which is on both sides of it

In conflict with evidence from younger palaeontological and potassium-argon (K-Ar) dating, which may reflect later episodes, this suggests that the original oceanic crust composing the island was formed at the Indian-Antarctic accreting mid-oceanic ridge around the time of anomaly 7 (27 Ma B.P.).

Key Words: oceanic crust uplift, magnetic anomalies, sea-floor history, Macquarie Island.

\section{INTRODUCTION}

The tectonic and physiographic expression of Macquarie Island and the surrounding region (fig. 1) is the result of oblique compression (transpression) between the Indian/ Australian and Pacific oceanic plates near to their common boundary. This boundary, south of New Zealand, lies within the Macquarie Ridge Complex, an arcuate system of ridges and troughs, extending from the Macquarie triple junction between the Indian, Pacific and Antarctic plates near $62^{\circ} \mathrm{S}$, $160^{\circ} \mathrm{E}$ (Sykes 1970) to the Alpine Fault of the South Island of New Zealand. The major physiographic element of the complex is an arcuate ridge (the Macquarie Ridge) with a trench (the Macquarie Trench) to the east in the central area and a trench to the west in the northern area (Puysegur) and the southern area (Hjort).

Geological and geophysical studies of the Macquarie Ridge began with the New Zealand programme to investigate the marine geology of the New Zealand subantarctic sea floor (Summerhayes 1969). Reconnaissance geophysical investigations in the region were later carried out by Lamont-Doherty Geological Observatory vessels Vema and Conrad, and were expanded between 1968 and 1971, using the USNS Eltanin. Dat a were also collected during a cruise by the Japanese vessel Umitaka-Maru and during aeromagnetic studies by the US Navy Oceanographic Office. In the Macquarie Island region, marine magnetic and bathymetric data were collected, primarily by the author, from the Australian National Antarctic Research Expedition (ANARE) relief vessel Nella Dan between 1970 and 1973.

Magnetic lineations have been used to resolve the sea-floor spreading history between Australia and Antarctica (Weissel 1972, Weissel \& Hayes 1971, 1972, Weissel et al. 1977) and in the Pacific plate south of New Zealand (Christ offel \& Falconer 1972). The broad crustal structure and tectonic history of the Macquarie Ridge Complex and the Macquarie Island region has been discussed by Hayes \& Talwani (1972), Woodward (1973), Williamson \& Johnson (1974), Williamson (1974, 1975), and Weissel et al. (1977), utilising a predominantly marine geophysical data base, and by Ruff \& Cazenave (1985), using SEAS AT data.

Analyses of sea-floor spreading magnetic lineations and gravity from Macquarie Island imply that the origins of the rocks of Macquarie Island were mainly at the Indian/AustralianAntarctic spreading centre, probably around 27 Ma B.P. - anomaly 7 time (Williamson 1974 . 1978, Williamson et al. 1981). Subsequent rotation of island segments, probably during uplift of Macquarie Island, has been demonstrated by Williamson (1978) and Varne \& Rubenach (1972). 


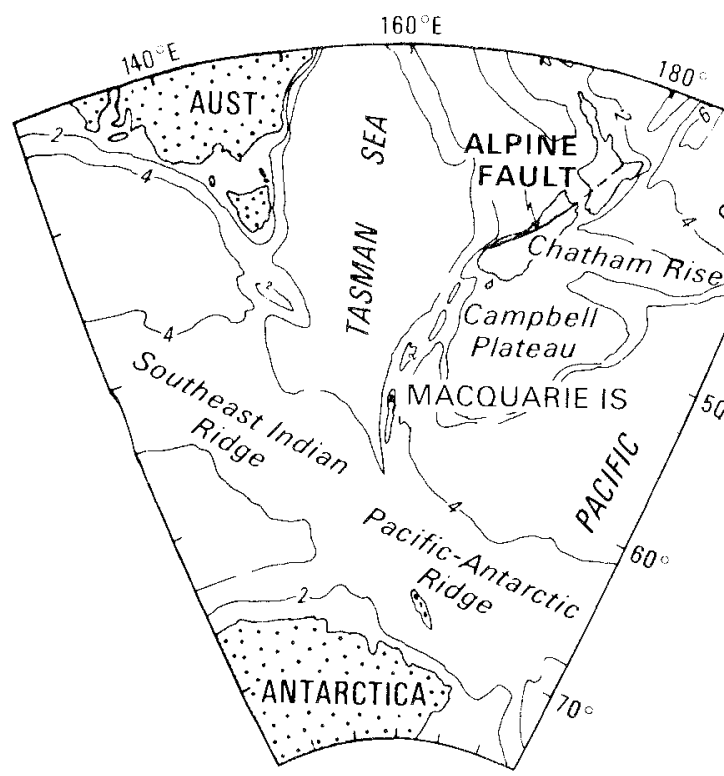

This paper represents a review, and, for the palaeomagnetic component, a reassessment of the geophysical and geological studies relating to the broad structure and origins of the Macquarie Island region, as a basis for future study.

\section{MORPHOLOGY \\ Macquarie Ridge Complex}

The morphology of the major segments of the Macquarie Ridge Complex (figs 2 and 3) has been described earlier (Brodie \& Dawson 1965, Summerhayes 1969, Hayes \& Talwani 1972). Except for a number of breaks (sometimes pronounced), the ridge lies at a depth less than $2000 \mathrm{~m}$ between latitudes of $47^{\circ} \mathrm{S}$ and $57^{\circ} \mathrm{S}$. South of $57^{\circ} \mathrm{S}$ it becomes less regular and branches into two segments. The Macquarie Trench lies east of the Macquarie Ridge between about $51^{\circ} \mathrm{S}$ and $56^{\circ} \mathrm{S}$. It is a continuous deep over a distance of $550 \mathrm{~km}$. It reaches a maximum depth of $6000 \mathrm{~m}$ and is typically deeper than $5200 \mathrm{~m}$

The Emerald Basin, east of the Macquarie Trench, is characterised by numerous large seamounts and pronounced depressions, especially in the vicinity of $55^{\circ} \mathrm{S}-59^{\circ} \mathrm{S}$ (Hayes \& Talwani 1972) The basin lying to the west of the Macquarie Ridge is characterised by relatively low relief, generally less than $400 \mathrm{~m}$, and variable sediment thickness (Houty et al. 1971, Hayes \& Conolly 1972).

\section{FIG. I - Locality map}

Isobaths at 2, 4 and $6 \mathrm{~km}$

\section{Macquarie Island Region}

The bathymetry of the Macquarie isiand region (Summerhayes 1969) shows gentle gradients to the west of the island which continue down to the level of the ocean basin (fig. 3). Much steeper gradients occur to the east of the island and extend into the Macquarie Trench. The major bathymetric trends in the area parallel the Macquarie Ridge, with only minor irregularities along these trends. The Macquarie Ridge is consistently shallow and rises above sea level in the cases of Macquarie Island, Bishop and Clerk Islands to the south, and Judge and Clerk Islands to the north.

Macquarie Island itself trends northnortheasterly, paralleling the Macquarie Ridge in the region. The island is characterised by a narrow coastal strip with steep slopes up to an undulating plateau at a maximum elevation of about $400 \mathrm{~m}$. The island plateau is cut by a major valley between Bauer Bay and Sandy Bay.

\section{GEOLOGY}

\section{Macquarie Ridge Complex}

Dredge hauls along the Macquarie Ridge (Summerhayes 1969, Watkins \& Gunn 1970) obtained in situ tholeitic basalt, harzburgite peridotite, sodic olivine gabbro and troctolite, similar to such rocks observed on Macquarie Island The Macquarie Ridge Complex south of $51^{\circ} \mathrm{S}$ appears from these data to be composed of rocks similar to normal oceanic crust.

The Macquarie Ridge is virtually devoid of sediment cover, and sedimentation in adjacent areas is extremely variable (Houtz \& Mark 1972 Houtz et al. 1971, Hayes \& Talwani 1972). The sediments in the Macquarie Trench are generally variable in thickness (from zero to $1 \mathrm{~km}$ ) but are locally undisturbed and horizontally layered (Hayes \& Talwani 1972), with thick accumulations of sediments occurring in small enclosed basins (Houtz et al. 1971). 


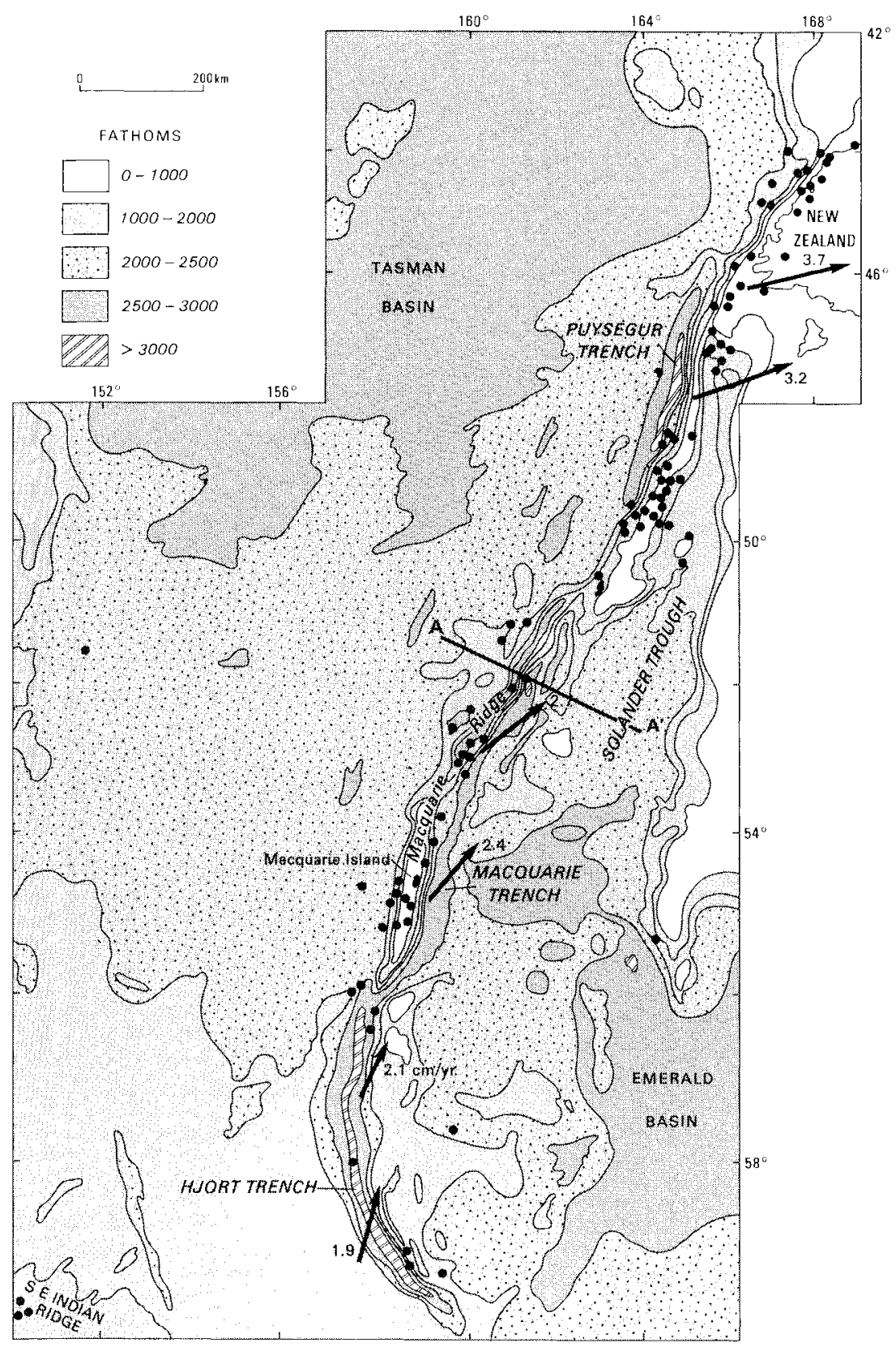

FIG. 2 - Generalised bathymetry of the Macquarie Ridge Complex showing seismicity (after Jones \& M(Cue, this volume) and vectors of relative plate motion of the Indian/Australian and Pacific plates in ' $\mathrm{m} / \mathrm{vr}$ (after Minster \& Jordan 1978); A-A' is the location of the gravity profile shown in figure 6. 


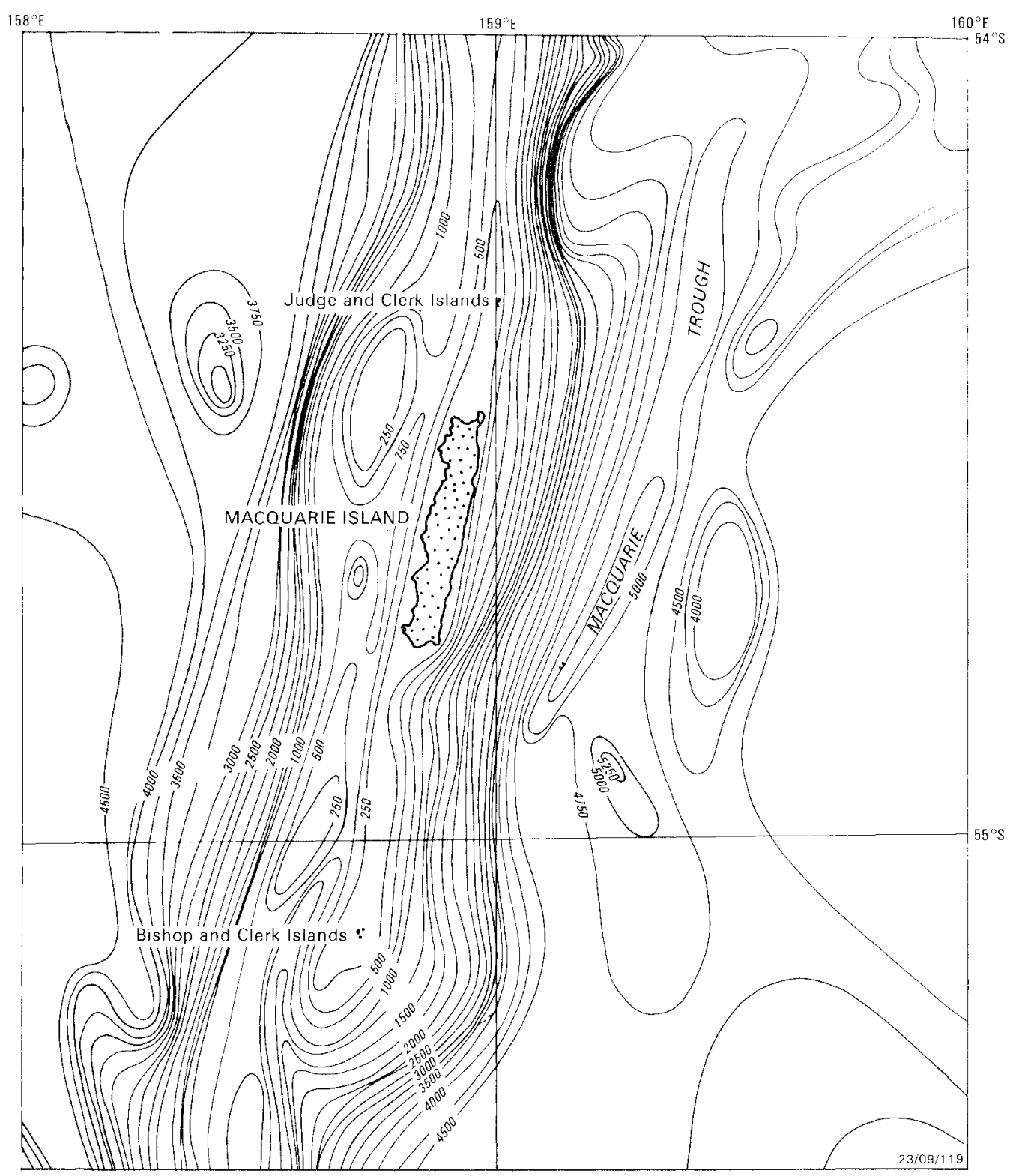

FIG. 3 - Bathymetry of the Macquarie Island region contoured in metres (after Summerhayes 1967). 


\section{Macquarie Island}

Early work carried out on Macquarie Island by Mawson (1943) has largely been superseded by more detailed work (Varne et al. 1969, Varne \& Rubenach 1972, Quilty et al. 1973, Griffin \& Varne 1980, Griffin 1982, Christodoulou et al. 1984). Varne \& Rubenach (1972) concluded that the island is formed of fault-bounded blocks. The northern part of the island is described as composed mainly of serpentinised peridotites, gabbros, and dolerite dyke swarms (fig. 5), and the southern part of extrusive rocks (fig. 4) which occur both as basaltic lava and as basaltic volcanic breccias Parallel dolerite dykes cut the lavas, volcanic breccias and associated sediments in all parts of the island, but there is no continuous gradation from areas of extrusive rocks cut by dykes into the areas of dyke swarms. Globigerina ooze occurs as interstitial materials in the pillow lavas, and poorly preserved coccoliths have been found at North Head.

The detailed structure and stratigraphy of the extrusive rocks of the island are complex and poorly understood. The pillow forms of some lavas imply that these have been tilted or near-vertical attitudes, but the steepest dips which could be reliably measured on lava flows with interbedded mudstone are about $45^{\circ}$. These flows were presumably horizontal or near-horizontal at the time of deposition. Many high and low angle faults cut the extrusive rocks.

Dykes cut the interbedded lava flows, breccias and sediments as a series of parallel sheets and do not intersect one another. Acute angles between the planes of the dykes and the bedding planes of the extrusive rocks are almost always large, no matter how steep the inclinations of the bedding planes, implying that the dykes were originally steeply inclined intrusions into relatively flat-lying extrusive rocks, and that the tilting occurred subsequently. In addition, the strikes of the tilted lava flows, breccias, and sediments are parallel or nearparallel to the strikes of the dykes that cut them. Seemingly, therefore, the axes about which the tilting took place must have been approximately horizontal and parallel to the dyke-bedding plane intersections (Varne \& Rubenach 1972).

In the northern part of the island, coarsegrained intrusive rocks representing deeper levels in normal oceanic crust are exposed. The serpentinised peridotites are usually massive rocks. The only layering interpreted as compositional occurs at Eagle point, where adjacent layers differ in their proportions of serpentinised olivine and ortho-

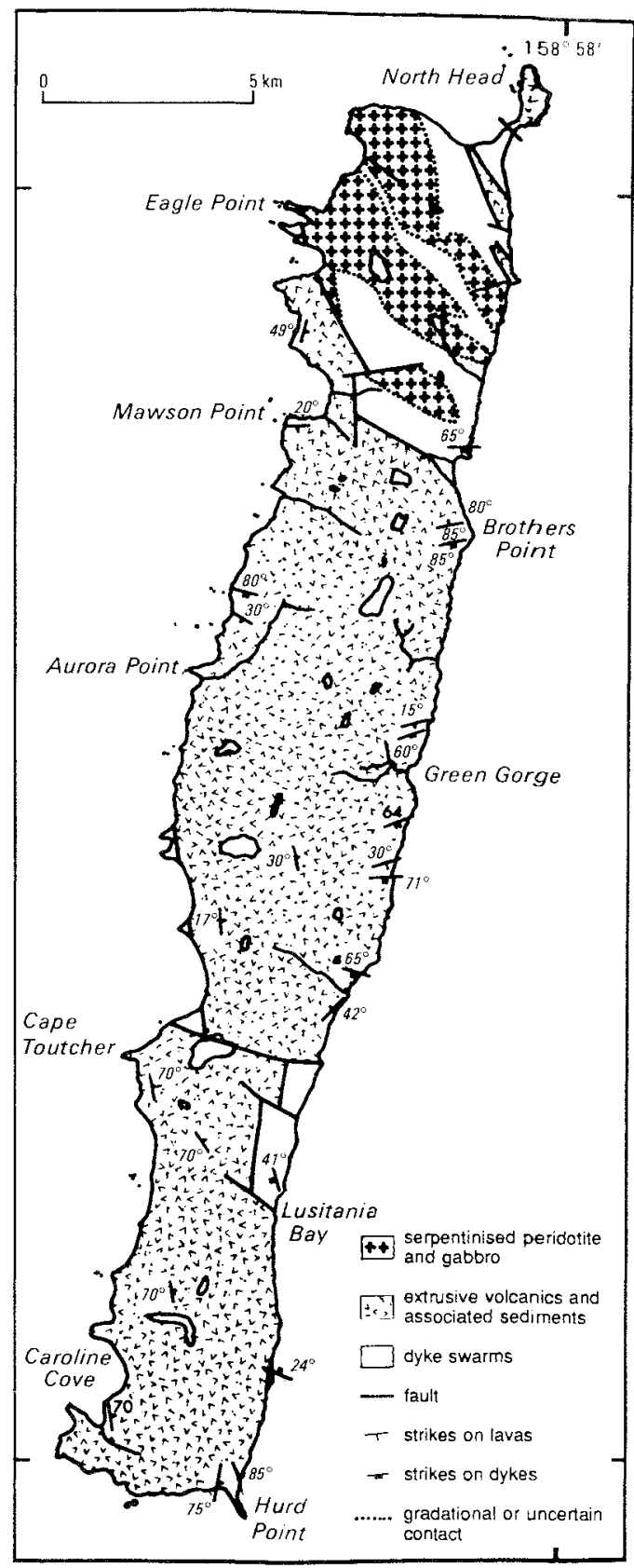

FIG. 4- Generalised geological map of Macquarie Island with superficial deposits omitted (after Varne \& Rubenach 1972). 
pyroxene. The style and regularity of this layering are similar to that found in cumulate rocks, and the layers a re continuous over the length of the outcrop. A layered gabbro complex disturbed by faulting and dyke swarm emplacement occurs in the northwest section of the island, and large outcrops showing spectacular layering are exposed.

Varne \& Rubenach (1972) argued that the lack of schistosity or penetrative cleavage in the metamorphosed basalts and dolerites in the north of the island, and the survival of igneous textures, indicate that the metamorphism was not accompanied by deformation, and was similar in nature to burial metamorphism.

Petrographic analyses of rocks from $\mathrm{Mac}$ quarie Island by Varne \& Rubenach (1972) show the majority of the dolerites and basalts are similar to normal ocean crust. On the basis of trace element studies, the rocks from Macquarie Island also clearly correspond to the ocean-floor basalts, although some variation in the trace element content in the rocks occurs (Varne \& Rubenach 1972, Griffin \& Varne 1980).

Although Macquarie Island geologically forms part of the crest of the Macquarie Ridge, the rocks of the island were not, in general, formed during tectonic evolution and emergence of the ridge within the last $10 \mathrm{Ma}$. This is supported by the observation that some of the freshest and presumably youngest volcanic rocks on Macquarie Island are associated with sediments that appear to be of Miocene age (11 25 Ma) (Quilty et al. 1973).

\section{CRUSTAL STRUCTURE AND TECTONIC HISTORY}

During the last $10 \mathrm{Ma}$ and up to the present time, the dominant motion between the Indian Australian and Pacific plates south of New Zealand has been interpreted as mainly transcurrent, with compression particularly at the Hjort and Puysegur Trenches, where varying degrees of nascent subduction of the Indian plate are indicated from earthquake studies by Banghar \& Sykes (1969) and from studies of relative plate motion by Weissel (1972), Hayes \& Talwani (1972), Hayes et al. (1972) and Weissel et al. (1977).

\section{Seismicity}

Studies of the seismicity of the Macquarie Ridge Complex have been made by Cook (1966) and Barazangi \& Dorman (1969). Seismic epicentres (Barazangi \& Dorman 1969, Jones \& McCue, this volume) show zones of intense activity at the southern end of New Zealand, between about $49^{\circ} \mathrm{S}$ and $53^{\circ} \mathrm{S}$, and at about $56^{\circ} \mathrm{S}$. First motion studies have been made on events from the Macquarie Ridge by Bangar \& Sykes (1969), Sykes (1967, 1970), Johnson \& Molnar(1972), Ruffet al. (1982) and Jones \& McCuc (this volume). Results of Johnson \& Molnar (1972) indicate that underthrusting of the Tasman Sea exists along the Macquarie Ridge Complex south to about $52^{\circ} \mathrm{S}$ Dextral strike-slip motion is interpreted on a fault plane approximately parallel to the Macquarie Ridge at $56.2^{\circ} \mathrm{S}$ while, for an event at $57.5^{\circ} \mathrm{S}$ formal faulting is interpreted. Jones \& McCue (this volume) show dextral strike slip motion for the Macquarie Island region.

Johnson \& Molnar (1972) concluded that the pole of rotation of the Australian-Pacific plate is located east of and close to the ridge, at about $56-57^{\circ} \mathrm{S}$. Ruff et al. (1982), however, have generated focal mechanism solutions, in basic agreement with the globally derived R $\mathrm{M} 2$ rotation pole of Minster \& Jordan (1978), that place the pole at $60.5^{\circ} \mathrm{S}$ and imply transpression of varying degrees for the whole Macquarie Ridge complex. That compression along the plate boundary is a recent activity is supported by the plate tectonic reconstruction of Molnar et al. (1975) and the studies of Walcott (1978) and Scholy et al. (1973). These studies indicate that, prior to $10 \mathrm{Ma}$ B.P., the Macquarie Ridge was characterised by strike-slip and spreading motions.

\section{Gravity}

The gross crustal structure associated with the central Macquarie Ridge Complex has been investigated using gravity data. Marine gravity data over this area have been inverted to show a progressive thickening of the Indian/Australian oceanic crustal layer from approximately 7 to $14 \mathrm{~km}$, over a $200 \mathrm{~km}$ distance as the ridge is approached from the west (Williamson \& Johnson 1974). A root zone, some $30 \mathrm{~km}$ wide and approximately $4 \mathrm{~km}$ thick, is indicated not symmetrically beneath the Macquarie Ridge itself but displaced towards the trench. Another root zone, approximately $50 \mathrm{~km}$ wide and $3 \mathrm{~km}$ thick, within the Emerald Basin to the east of an unthickened segment of oceanic crust immediately west of the Macquarie Trench, appears to be associated with a local bathymetric high, possibly caused by volcanic activity (Hayes \& Talwani 1972) or the presence of an ancient spreading ridge associated with the opening of the Emerald Basin. 


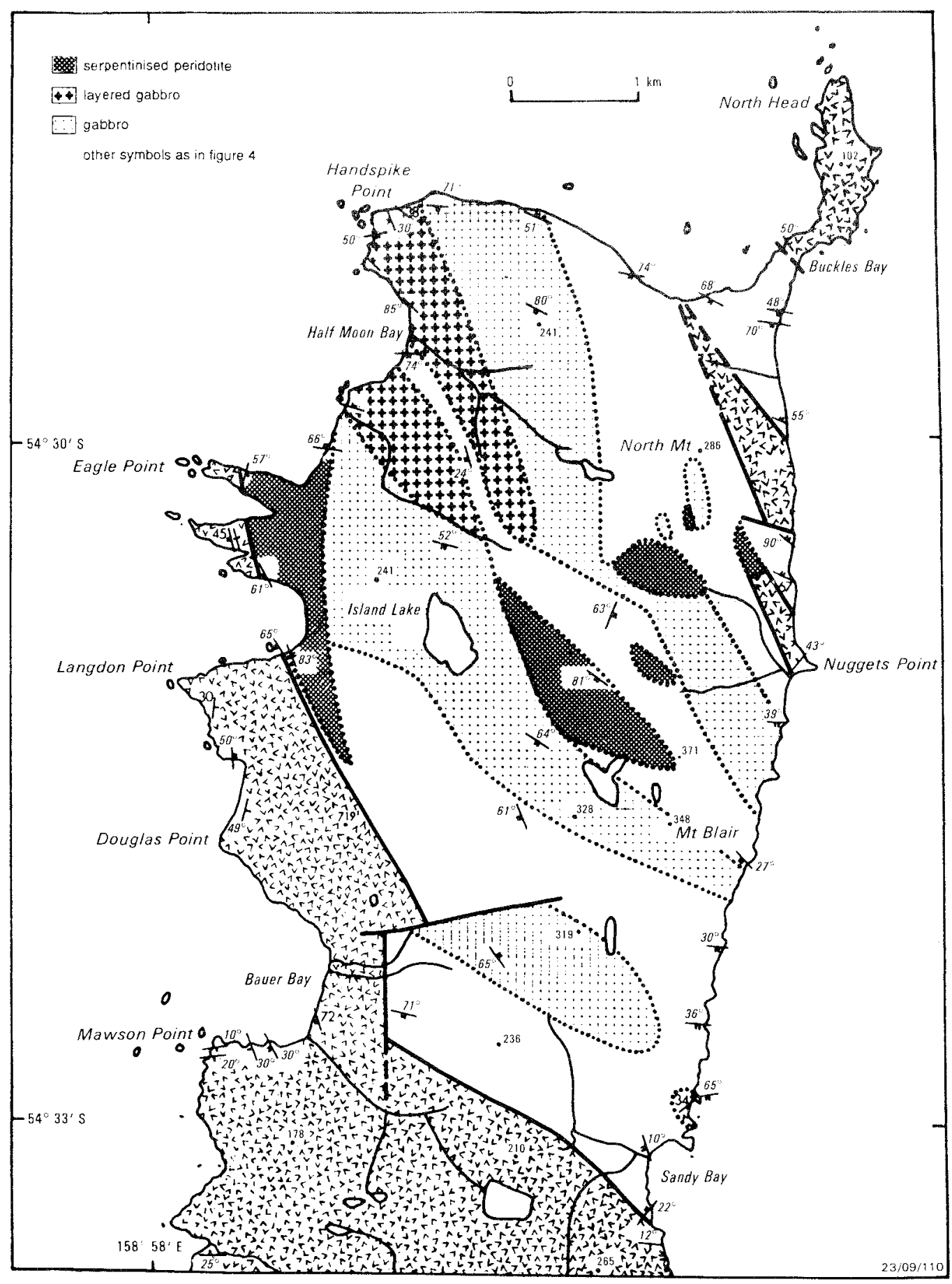

FIG.5-Geological map of the northern part of Macquarie Island with superficial deposits omitted (after Varne \& Rubenach 1972). 


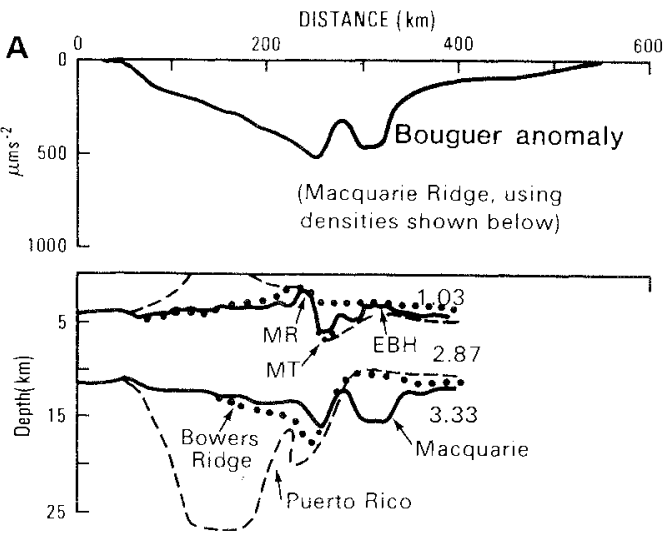

B

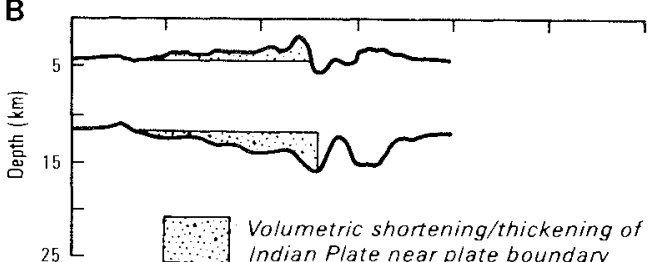

FIG. 6 - (A) Crustal structure (lower surfaces) over the central Macquarie Ridge Complex, arrived at by inversion of Bouguer gravity anomaly data, and bathymetry (upper surfaces); demonstrating incipient subduction compared to progressively more developed subduction for the Bowers Ridge and Puerto Rico Trench region. MR is Macquarie Ridge; $M T$ is Macquarie Trench; EBH is Emerald Basin High. Densities used for the inversion are also shown. Location of profile is shown in figure 2. (Afier Williamson 1975.) (B) Stippled area shows the crustal thickening relative to the original Indian/Australian oceanic plate during the formation of the Macquarie Ridge, which could accommodate crustal shortening of $65 \mathrm{~km}$.

Asymmetry similar to that observed for the central Macquarie Ridge (excluding the Emerald Basin feature) is typical of island arc systems (fig. 6). The Tonga-Kermadec area has been investigated by Talwani et al. (1961), the mature Puerto Rico Trench region, by Talwani, Sutton \& Worzel (1959), the nascent Bowers Ridge Complex by Kienle (1971), and the Japan region by Tomoda (1973). All the above regions exhibit asymmetry in the free air and Bouguer gravity anomalies, and in their inferred crustal structure. Also, in island arc regions, negative isostatic anomalies are associated with the trench and positive isostatic anomalies with the arc or ridge (Heiskanen \& Vening Meinesz.
1958, Tomoda 1971). Similar relationships are observed for the Macquarie Ridge Complex (Hayes \& Talwani 1972). For well-developed island arc systems, such as that associated with the Puerto Rico Trench (Talwani, Sutton \& Worzel 1959), where extensive loading by island arc volcanics has occurred, this asymmetry is not as marked as it is in the case of partially developed systems, such as in the western part of the Bowers Ridge. In the latter area, crustal thickening increases towards the trench, with the root zone occurring beneath the trench. This is most similar to that observed for the central region of the Macquarie Complex. A similar, though less pronounced, crustal structure occurs in the Mendocino Escarpment, where a root zone is present and is displaced from the bathymetric high towards a buried trough feature masked by thick sediments (Talwani, Worzel \& Landisman 1959). This structure would appear to be the result of secondary intra-crustal compressive forces and to represent the oppposite case to that of the "leaky transform fault" which reflects secondary intracrustal extensional forces.

The various cases cited can be used to show progressive stages in the development from an incipient to a mature subduction zone (fig. 6). The asymmetry of gravity signature and inferred crustal structure of the central Macquarie Ridge Complex (along with the shallow seismicity) correspond to those of an incipient subduction system and support the predicted compressional component of relative plate motion between the Indian and Pacific plates in the region, as shown in figure 2. It is further impled that the Indian/Australian-Pacific plate boundary occurs at the Macquarie Trench where incipient westward dipping subduction of the Pacific plate is now occurring. For the northern and southern ends of the complex, gravity anomalies and inferred crustal structures (Woodward 1973) both show thickening towards the ridge. In the case of the Puysegur Trench, however, a more pronounced asymmetric root zone is defined. This, together with the occurrence of a considerably more pronounced component of underthrusting of the ocean plate in the area (Johnson \& Molnar 1972), is consistent with a better developed subduction zone in that region.

Loss of around $65 \mathrm{~km}$ of oceanic crust of the Indian plate, due to crustal shortening, and thickening to around $150 \%$ (fig. 6) is implied by gravity results in the central Macquarie Ridge Complex north of Macquarie Island. The area is north of the zone where Weissel et al. (1977) interpreted crustal loss from sea-floor spreading magnetic anomaly patterns, which they considered 
to be due to possible subduction or entrapment by the Pacific plate. Investigation of crustal loss in the area of the gravity profile was not possible from magnetic studies due to lack of data (J. Weissel, pers. comm.). The oceanic crust in the Macquarie Island region has probably been further thickened and shortened, compared with the location of the gravity profile, to accommodate the additional uplift of the ridge to above sea level. Crusta thickening at Macquarie Island and close to the boundary between the Indian/Australian and Pacific plates in general, is the result of transpressional forces, and is thus likely to be associated with structural features, including "flower structures", that usually occur within transpressional regimes (M. Etheridge, pers. comm.).

Uplift of some rocks of Macquarie Island by approximately $10 \mathrm{~km}$ during crustal thickening is indicated, since harzburgites representative of the lower ocean crust formed at depths of $5 \mathrm{~km}$ (Griffin \& Varne 1980) have been uplifted to outcrop on Macquarie Island from water depths of around $5 \mathrm{~km}$. The high dips of lavas on the island and the rotation of the south of the island relative to the central island block, by $55^{\circ}$ clockwise around a vertical axis, which has been demonstrated from palaeomagnetic results (Williamson 1978), are also apparently associated with the transpression along the ridge crest (fig. 7). Rotation of rocks on the island is also supported from geological argument (Varne \& Rubenach 1972).

The Bouguer gravity anomaly associated with Macquarie Island shows only a Bouguer gravity gradient across the island (Williamson \& Rubenach 1972). This is inconsistent with local isostatic compensation of the island but consistent with deepening of the Moho towards the plate boundary at the Macquarie Trench east of Macquarie Island, as indicated by inversion of the gravity profile (fig. 6 ).

The characteristics of the Bouguer gravity anomalies and the inferred crustal structure over the central Macquarie Ridge Complex (fig. 6) are dissimilar to those over accreting mid-ocean ridges (e.g., for the Mid-Atlantic Ridge and the East Pacific Rise (Talwani et al. 1965), for the PacificAntarctic Ridge (Tomoda 1971), for the North Atlantic and Rykjanes Ridges (Talwani et al. 1971)). These typically show gravity lows which are symmetrical about the ridge axis.

\section{SEASAT Data}

SEASAT data, along with earthquake seismicity data collected over the Macquarie Ridge Complex
(Ruff \& Cazenave 1985), show geoid anomalies over the Hjort and Puysegur Trenches which are interpreted as being characteristic of subduction zones (fig. 8). They display the characterist ic geoid signature of mature subducting trenches. This includes a narrow geoid minimum of $5-20 \mathrm{~m}$ amplitude and $100-400 \mathrm{~km}$ width directly at the trench axis. From the trench to the landward side there is a geoid high, coinciding generally with the island arc. Superimposed on this short wavelength variation is a broad positive anomaly in the geoid, with a maximum in the vicinity of the trench

The Hjort Trench region is interpreted (Ruff \& Cazenave 1985) as an oblique subduction zone

normal palaeomagnetic

directions

reversed directions
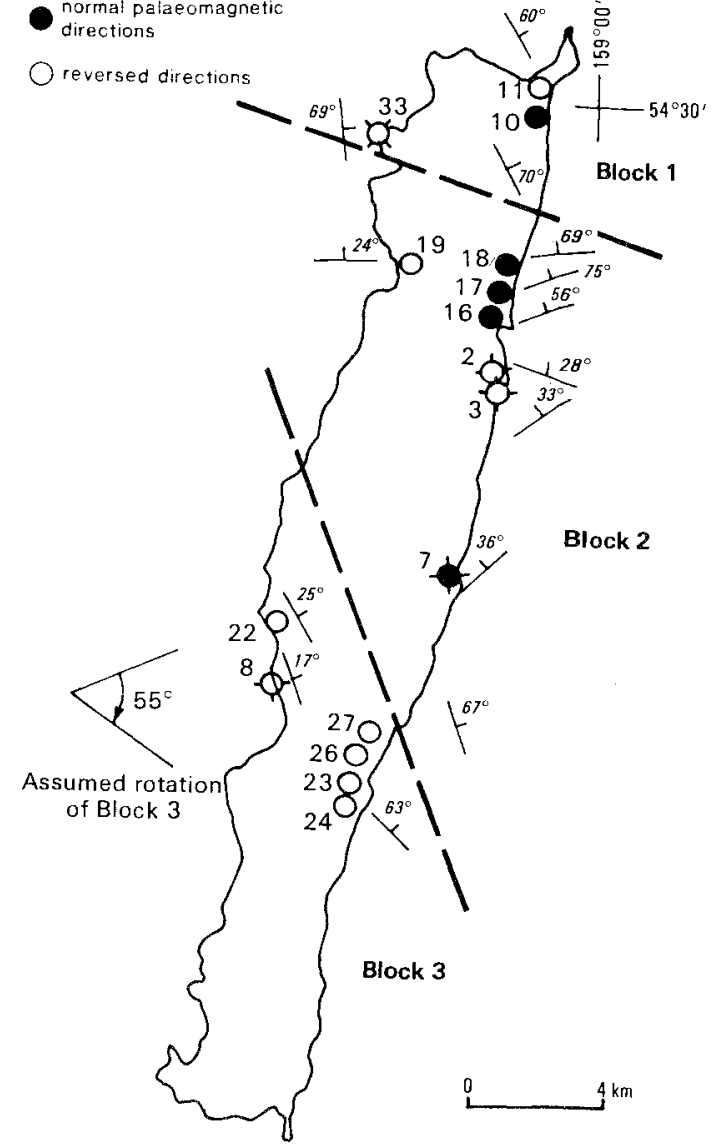

FIG. 7 - Rotation of the southern block (3) of Macquarie Island relative to the central hlock (2) during crustal thickening and uplift of the island, inferred from requirements for statistical compatability of apparent palaeomagnetic poles from the central and southern areas of the island. (After Williamson 1978.) 

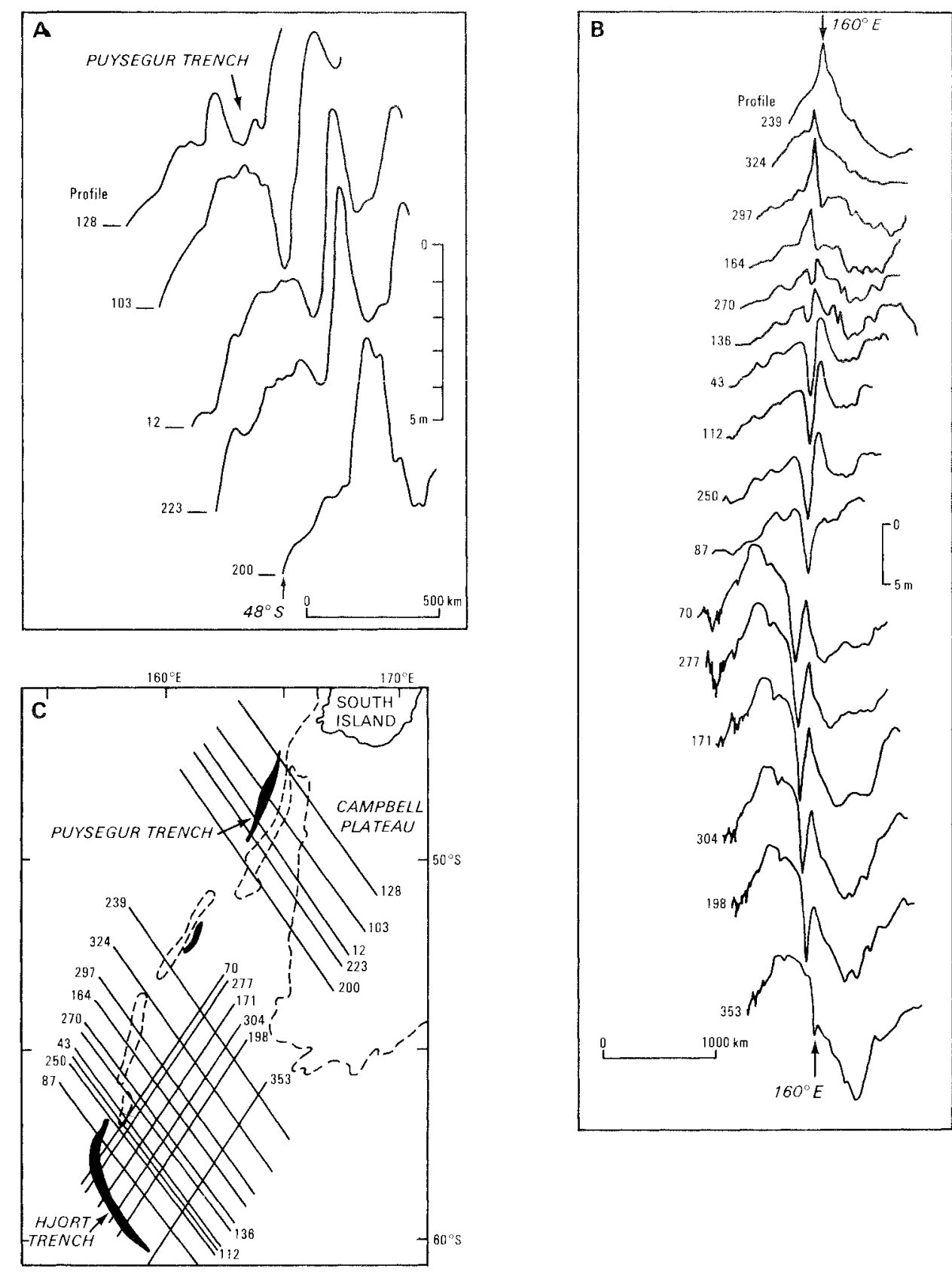

FIG.8 - SEASATgeoid anomalies over the Macquarie Ridge Complex (A and B) andlocations of profiles (C) (after Ruff \& Cazenave 1985). Anomalies over the Puysegur (A) and Hjort Trenches (B; profiles 43-353) are interpreted as indicating nascent subduction. Anomalies over the Macquarie Trench (fig. B; profiles 239-136) are non-diagnostic consistent with incipient subduction. 
similar to the Aleutian-Komandorski region on the basis of its geoid anomaly, while the geoid anomaly of the Puysegur Trench region is considered to be consistent with a nascent subduction zone environ ment. The geoid anomalies over the central Mac quarie Ridge are non-diagnostic, but they are clearly not consistent with more than incipient subduction in that region: in particular, the characteristic narrow geoid minimum directly over the trench for mature subduction zones is absent.

\section{ORIGIN OF MACQUARIE ISLAND ROCKS}

\section{Regional Pattern of Sea-Floor Spreading Magnetic Anomalies}

The formation of the eastern Indian/ Australian oceanic plate south of Australia, to which the Macquarie Island rocks belong, has been investigated from sea-floor spreading magnetic anomalies (Le Pichon \& Heitzler 1968, Weissel \& Hayes 1971, Weissel et al. 1977) tied to the geomagnetic time-scale of Heitzler et al. (1968). The magnetic anomaly lineations on the Indian/ Australian plate south of the Resolution Ridge at $48^{\circ} \mathrm{S}$ strike eastnortheast and are interpreted as resulting from formation of Cainozoic oceanic crust at the Indian-Antarctic Ridge (fig. 9) Anomalies to anomaly 21 are identified. Anomaly lineations are offset in detail (fig. 10) by fracture zones striking northnorthwest. To the west of the Macquarie Ridge Complex north of $48^{\circ} \mathrm{S}$ (fig. 9), the magnetic anomalies trend in a northnorthwesterly direction and have been correlated with specific sea-floor spreading anomalies associated with the opening of the Tasman Sea (Ringis 1972 , Hayes \& Ringis 1973, Weissel et al. 1977).

An interpretation of the magnetic anomalies on the Pacific plate to the southeast of the Macquarie Ridge Complex shows the maximum age of oceanic crust in the region is about $80 \mathrm{Ma}$ anomaly 32 ( $78 \mathrm{Ma}$ ) occurring close to the Campbell Plateau (Christ offel \& Falconer 1972). A sequence down to anomaly 25 occurs south of this. The next reliable identification, however, is of anomaly 5 . which occurs close to the Pacific-Antarctic spreading ridge. The results imply that distinct periods of sea-floor spreading have occurred within this region, as many of the sea-floor spreading anomalies between 5 and 25 do not appear to be represented in the area (Christoffel \& Falconer 1972, Adams \& Christ offel 1965).

To the east of the Macquarie Ridge, at about $51.5^{\circ} \mathrm{S}$ and $162.5^{\circ} \mathrm{E}$, anomaly lineations are poorly

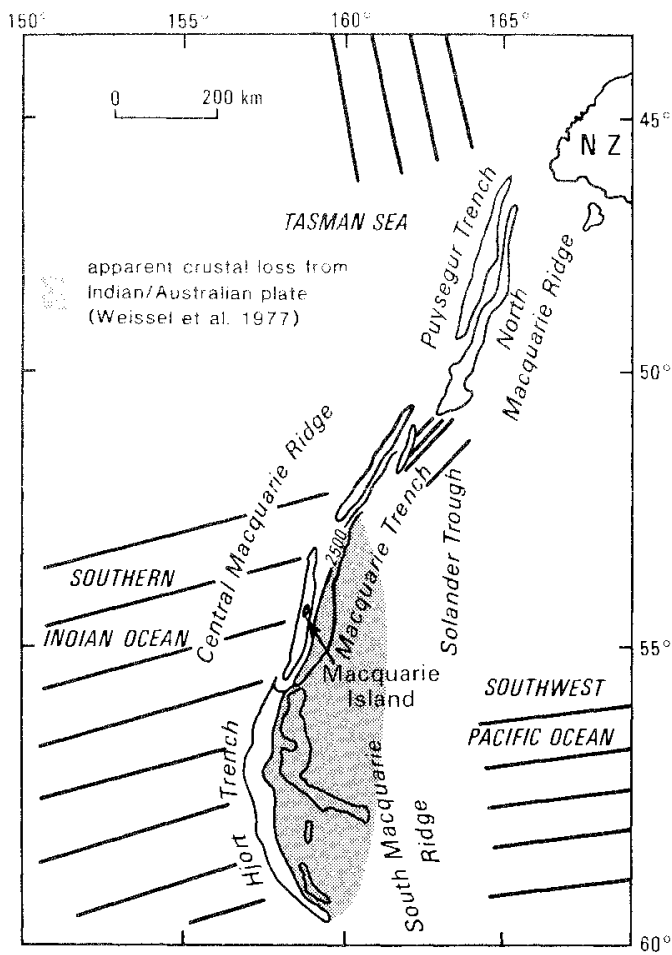

FIG. 9 - Generalised trends of marine magnetic lineations surrounding the Macquarie Ridge Complex. For the trenches 2500 fathom contours are shown.

defined but appear to trend approximately parallel to the ridge (Hayes \& Talwani 1972). However, the tentative correlations may reflect structure in the sea floor rather than the normal polarity reversals. The direction of magnetic lineations has also not been established in the Emerald Basin which lies to the south of the above area. The orientation of tracks and the apparent wavelengths displayed in that area, suggest that, if lineations are present, they are probably oriented in an approximately northnortheasterly direction.

\section{Sea-Floor Spreading Magnetic Anomalies in the Macquarie Island Region}

The history of oceanic crust around Macquarie Island was investigated, using magnetic data collected along profiles parallel to the Macquarie Ridge from the Nella Dan (Williamson et al. 1981). Anomaly $7(27 \mathrm{Ma}$ ) is identified, on Nella Dan data, to the west of Macquarie Island (fig. 10), and anomalies 8 and 9 north of the island. 
These anomalies have been identified with greater confidence due to their existence as part of a longer sequence of anomalies, which extend from anomaly 7 to ano maly 21 , and are observed in the Nella Dan data between Melbourne and Macquarie Island. The magnet ic lineations parallel sea-floor spreading anomalies on the Indian/Australia plate west of
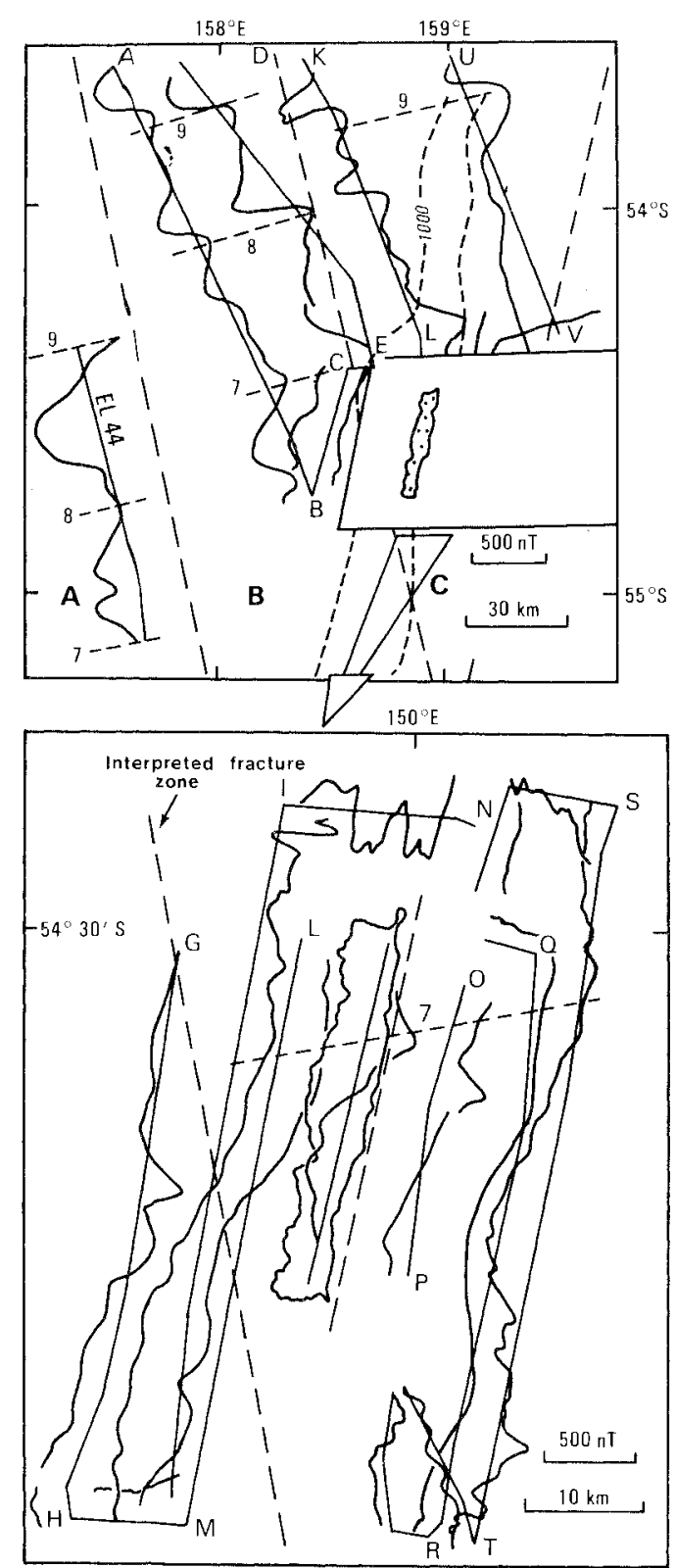

the island and terminate east of Macquarie Island at the Macquarie Trench, which is interpreted to be the Indian/Australian-Pacific plate boundary; this implies that Macquarie Island occurs on the Indian/Australian plate. Offsets in the magnetic lineations suggest the presence of two minor transform faults to the west of the island. These are expressed as a deflection to the north in the magnetic lineations interpreted in the broader study of Weissel et al. (1977). To the west of the island, anomalies 8 and 9, observed in the Eltanin 44 data, occur about $80 \mathrm{~km}$ south of the same anomalies on the Nella Dan tracks east of a separating transform fault. A second transform fault, with a small offset, appears to trend in a northnorthwesterly direction close to the west coast of Macquarie Island. Here, anomaly 9 is interpreted to occur about $20 \mathrm{~km}$ to the south of the same lineations further west. Anomaly 9 is tentatively correlated over the ridge north of Macquarie Island. The shape of the anomaly is distorted, however, probably as a result of the magnetic anomaly associated with the ridge.

\section{Sea-Floor Spreading Magnetic Anomaly Data on Macquarie Island}

A magnetic anomaly lineation is interpreted as crossing Macquarie Island (fig. 10). The preferred identification is that it is anomaly $7(27 \mathrm{Ma})$, since the broad features of the upwardly continued magnetic anomaly profile (to $1 \mathrm{~km}$ ) along the island can be correlated with anomaly 7 , interpreted on the adjacent marine magnetic profiles. In the onland data, the character and anomaly widths of the magnetic high and the associated low to the south are also similar to those of anomaly 7 and the associated magnetic low in the adjacent marine

FIG. 10 - Marine magnetic anomaly profiles in the vicinity of Macquarie Island to the west of the plate boundary at the Macquarie Trench. Identified anomalies are from the Heirtzler et al. (1968) sequence. Inferred fracture zones are interpreted from offsets of the anomaly sequences. The lower part of the figure shows marine magnetic anomaly profiles close to Macquarie Island. Also shown is the main north-south profile along the island. upwardly continued to a level of $1 \mathrm{~km}$, which is similar to the depths to sea floor on the marine profiles. The tentative correlation of the anomaly on either side and across the island corresponds to anomaly 7 (27 Ma B.P.). 
data. This implies the presence of remanent seafloor spreading anomalies over, and generated by, the island lavas.

Magnetic properties of the Macquarie Island rocks, confirming the ability of the basalt lavas on the island to contribute to sea-floor spreading magnetic anomalies, have been reported by Williamson (1974, 1978), Butler \& Banerjee (1973) and Butler et al. $(1975,1976)$.

Modelling of the main north-south onland magnetic profile from Macquarie Island (Williamson et al. 1981) demonstrates that using palaeomagnetic, magnetic property and structural data from the island, the upwardly continued magnetic anomaly profile can be modelled as a remanent profile caused by a sea-floor spreading sequence of magnetic reversals. The model is complex, but mainly refiects the effect of primary remanent magnetic properties of the rocks, the directions of which have been adjusted by subsequent block faulting and tilting, probably related to the formation of the ridge and island. Minor magnetic features of the profile appear to be related to demagnetisation, possibly due to local weathering associated with major zones of faulting (fig. 11) The magnetic anomaly profile cannot be modelled as induced, using the magnetic susceptibilities measured for the island rocks (Williamson 1978). These could produce magnetic anomaly amplitudes which are only around 50\% of those observed. However, the observed anomalies can be produced by remanent magnetic polarity reversals, since the Koenigsberger ratios (normal remanent magnetisation/magnetic susceptibility - NRM/SUS) of the island lavas are close to unity (Williamson 1978).

The final model for the distribution of normal and reversed directions of remanent magnetisation within the pillow lavas of the island has a broad section of reversed polarity followed, to the south, by a broad normal polarity section, interrupted in the centre of the island by a narrow zone of reversal (fig. 11). This is qualitatively similar to the sequence of reversals surrounding anomaly 7 of the Heirtzler et al. (1968) series. If the pattern of reversals along the island does correspond to the anomaly 7 sequence, however, an apparent compression of the sequence relative to that further to the west is observed. This could be associated with transpressional structures at the ridge crest which accommodated greater crustal thickening in the formation of the island.

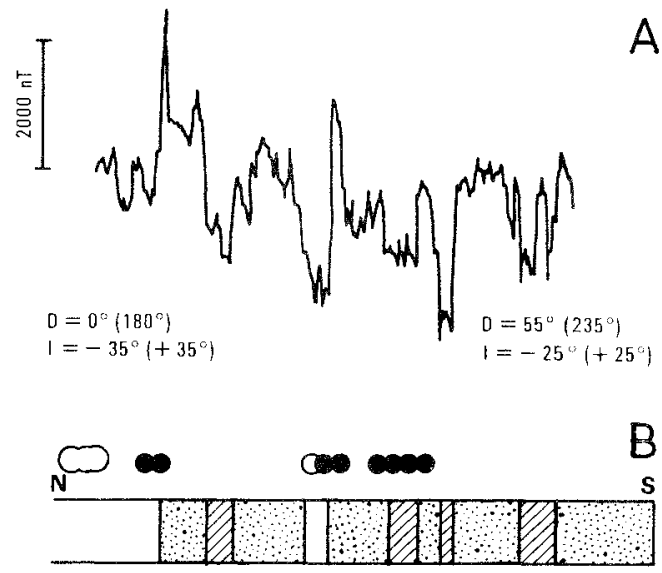

A

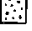

- normol magnetisotion

$\square$ Oreversed magnetisation

Q assumed to be demagnetised

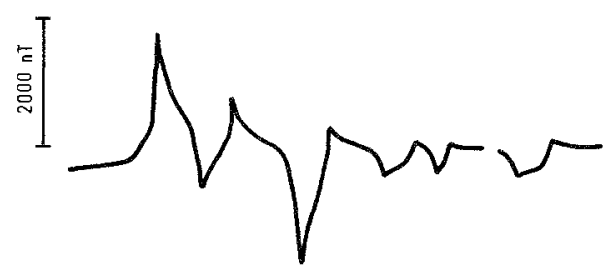

C

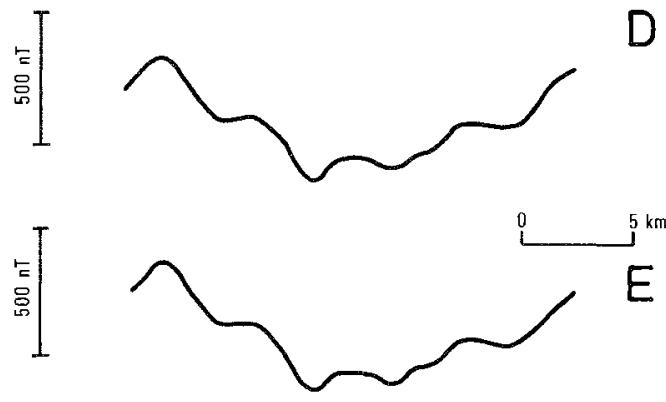

FIG. II - Model for remanen I magnetic anomalies along the main north-south track of Macquarie Island. incorporating magnetic, palaeomagnetic and structural data; with (A) as the anomaly profile. (B) the inferred model, (C) the synthetic vertical component at a level of $2 \mathrm{~m}$, (D) at $1 \mathrm{~km}$ and $(E)$ the upwardly continued profile at a level of $1 \mathrm{~km}$. 


\section{Palaeomagnetic Data}

Palaeomagnetic apparent pole data from Macquarie Island (Williamson 1978) have been reviewed and recalculated (paper in prep.) in relation to the revised polar wander path for the Australian plate (Idnurm 1985). No unique apparent palaeomagnetic pole for Macquarie lsland is now considered possible from present data, due to the inability to resolve rotations around a vertical axis in relation to any simple structural model generated from other data. The possible range of poles in not inconsistent with inferences from marine magnetic data but cannot be said to uniquely support them.

\section{DISCUSSION} follows:

Geophysical results can be summarised as

(1) The delineation of a remanent sea-floor spreading magnetic anomaly lineation across Macquarie Island, with a trend similar to those on the Indian plate to the west, suggests that the rocks of the island were formed at the Indian/ Australian-Antarctic spreading ridge.

(2) The coincidence of the trends of Indian Australian plate sea-floor spreading lineations with the strike of dykes in the central region of the island is consistent with the model of dyke injection at a mid-ocean ridge, and further argues for the formation of the island rocks at the Indian/AustralianAntarctic spreading ridge.

(3) The interpretation of crustal structure from gravity data implies that the eastern extent of the Indian/Australian plate is at the Macquarie Trench, east of Macquarie Island, which again implies that the rocks of Macquarie Island were formed as part of the Indian/Australian oceanic plate.

(4) The preferred interpretation of the remanent magnetic lineation crossing Macquarie Island is anomaly $7(27 \mathrm{Ma})$. This interpretation is an extension of interpretations of remanent magnetic anomalies over the oceanic crust for the Indian Australian plate west of Macquarie Island. The interpreted age is considered to be correct within approximately $+3 \mathrm{Ma}$, which corresponds to the anomaly being misinterpreted anomaly 6 or 8 . Due to the structural complexity of the region such a misinterpretation may be possible. Detachment of oceanic crustal blocks at the ridge could contribute to this so that the age is more likely to be of anomaly 8 than 6 , given that the motion of the Indian/Australian plate relative to the Pacific plate is dextral. That is, the age is more likely to be underestimated than overestimated. An age for
Macquarie Island oceanic crust of around $10 \mathrm{Ma}$ (anomaly 5) age, as suggested from recent K-Ar dating, would require either (a) that there is a spreading ridge jump of around $500 \mathrm{~km}$ to the north and also that the sea-floor spreading results published for the eastern Indian plate are seriously in error; or (b) that Macquarie Island crust was locally emplaced at the plate boundary; sea-floor spreading remanent anomaiy trends would then parallel the Macquarie Ridge, which does not appear to be the case.

The geophysical data, with the exception of the palaeomagnetic data, are broad scale and do not relate to specific rock samples, and certainly those data argue that the rocks of Macquarie Island in general were formed at the Indian/ Antarctic spreading ridge at around 27 Ma B.P.

A discrepancy exists, however, between geophysical and some palaeontological dating and all $\mathrm{K}$-Ar age estimates. Palaeontological data associated with rocks from North Head ("some of the freshest volcanic rocks") on the island have given ages of middle to early Miocene (Quilty et al. 1973). Recent K-Ardata reported by Varne (pers. comm.), however, give young ages, normally within the last $10 \mathrm{Ma}$, for rocks of the island. Those ages essentially correspond to the normally accepted time of uplift of the ridge and island estimated from geophysical data. K-Ar ages could not be obtained for the rocks used in the palaeomagnetic study because their preservation was not considered sufficiently good for that purpose.

The apparent discrepancy between the two sets of ages could reflect two factors:

(1) essentially different data sets relating, on the one hand, to original oceanic crust and later intrusive and extrusive activity (such as seamount activity) associated with the already formed oceanic crust or, on the other, to crustal compression during formation of the Macquarie Ridge; this could result in the fresher samples being more recent, which may be particularly relevant to samples from North Head which are unusually "fresh" samples; or

(2) inaccuracies in the relatively small number of palaeontological age determinations, due to poor preservation of specimens and misidentification; loss of residual argon, due to tectonic activity during the last $10 \mathrm{Ma}$, giving young and incorrect $\mathrm{K}$-Ardates, although some of these are ${ }^{39} \mathrm{Ar} /{ }^{40} \mathrm{Ar}$ dates, which are not as susceptible to Ar loss or alteration; dating simply reflecting time of uplift; or fortuitous correlation of unrelated geophysical anomalies. 
Some igneous episodes after the formation of the original oceanic crust are to be expected, however, particularly given the level of tectonic activity of the region and the nearness to the plate margin. This could suggest that factor (1) above is the dominant cause of the discrepancy. Nonetheless, it is important that investigations be carried out to resolve the discrepancy, and to this end more extensive palaeontological studies on sediments between lava layers from all areas of the island could be employed.

\section{CONCLUSION}

Macquarie Island is a rare example of uplifted oceanic crust. As such it is a geological enigma and a critical a rea for the study of ocean tectonics. The structure and physiographic expression of the island and the surrounding region are the result of a tectonic history of oblique compression (transpression) between the Indian/Australian and Pacific oceanic plates at their common boundary within the Macquarie Ridge Complex south of New Zealand. Intra-plate transpressive forces in this region resulted in the uplifted of oceanic crust of the Indian/Australian plate to form the Macquarie Ridge and Macquarie Island, and in incipient subduction of the Pacific oceanic plate at the Macquarie Trench. This uplift has been effected by thickening and shortening of the oceanic crust of the Indian/Australian plate, the amount of uplift being reduced by regional isostatic compensation of the increased crustal thickness. The transpressional regime has persisted during the last $10 \mathrm{Ma}$; prior to that time, strike-slip and extensional regimes occurred along the Macquarie Ridge Complex.

The uplift of Macquarie Island has been accompanied by tilting of rocks and rotation of the southern segment of the island, relative to the central segment, by about $55^{\circ}$ in a clockwise direction around a vertical axis. In the north, gabbro and serpentinite formed at depths of up to $5 \mathrm{~km}$ in the primary oceanic crust, are currently exposed above sea level. Structural tilting of the island lavas has not been sufficient to reverse the primary in situ directions of remanent magnetisation. Consequently, long wavelength remanent magnetic sea-floor spreading anomalies associated with areas of outcropping lavas in the centre and south of Macquarie Island correlate, with the same polarity, with similar features in marine magnetic data on the Indian plate on both sides of the island. Measured magnetic properties of the istand's igneous rocks confirm that their remanent magnetisations could contribute to sea-floor spreading magnetic anomalies, with the dominant contribution coming from the lava sequences and lesser contributions from gabbros and dolerites. The serpentinite samples measured do not exhibit stable NRM.

Sea-floor spreading magnetic anomaly 7 is tentatively correlated across Macquarie Island, indicating that oceanic crust, of which the island is composed, was formed at the Indian-Antarctic accreting mid-oceanic ridge around anomaly 7 time (27 Ma B.P.)

This is in conflict with evidence from younger palaeontological and $\mathrm{K}$-Ar dates from the island (from Miocene to Recent) which may reflect later metamorphic or igneous episodes after the establishment of the original oceanic crust. The youngest $\mathrm{K}$-Ar date, for instance, is on a metamorphic dyke from the sheeted dyke complex and reflects the timing of the closure of the metamorphic minerals as they cooled ( $R$. Varne, pers. comm.).

To date, broad tectonic studies have presented insights into the mode of formation of Macquarie Island, the origins of its dominant rock types and the nature and result of the large-scale structural movements which affected the region. The detailed structural configurations involved are, however, poorly understood. Future work could usefully investigate the inferred presence of transpressional structures on the island, associated with the crustal thickening and uplift of deep crustal rocks, assuming sufficient data reflecting stress and strain directions can be obtained. In addition, more extensive palaeontological studies could help to resolve discrepancies in the ages of the island rocks as interpreted from existing palaeontological, $\mathrm{K}-\mathrm{Ar}$ and geophysical data.

\section{ACK NOWLEDGEMENTS}

The work described here was carried out under the auspices of ANARE with assistance from many ANARE personnel. Constructive reviews by C.J. Pigram, B.D. Johnson and R. Varne have helped bring the text to its final form. 


\section{REFERENCES}

ADAM S, R.D. \& CHRISTOFFEL, D.A., 1965: Tota magnetic field surveys between New Zealand and the Ross Sea. J. Geophys. Res., 70: 805-814.

BANGHAR, A.R. \& SYKES, L.R., 1969: Foca mechanisms of earthquakes in the Indian Ocean and adjacent regions. J. Geophys. Res., 74(2): 632-649.

BARAZANGI, M.W. \& DORMAN, J., 1969: World seismicity maps, compiled from ESSA Coas and Geodetic Survey epicenter data, 1961-1967. Bull. Seism. Soc. Am., 59(1): $369 \ldots 380$.

BRODIE, J.W.\& DAWSON, E.W., 1965: Morphology of North Macquarie Ridge. Nature, 207 : $844-845$

BUTLER, R.F. \& BANERJEE, S.K., 1973: Magnetic properties of exposed oceanic crust on Macquarie Island. Nalure, 244(138): 115-118.

BUTLER, R.F., BANERJEE, S.K. \& STOUT, J.H. 1975: Magnetic properties of ocean pillow basalts from Macquarie Island. Nature, 257 $302 \cdot 303$

BUTLER, R.F., BANERJEE, S.K. \& STOUT, J.H., 1976: Magnetic properties of oceanic pillow basalts: evidence from Macquaric lsland. Geophys. J. R. Astro. Soc., 47: 179196

CHRISTODOULOU, C., GRIFFIN, B.J. \& FODEN, J., 1984: The geology of Macquarie Island. ANARE Res. Notes, 21

CHRISTOFFEL, D.A. \& FALCONER, R.K.H., 1972 Marine magnetic measurements in the southwest Pacific Ocean and the identification of new tectonic features. In Hayes, D.E. (Ed.): $A N 7$ ARCTIC OCEANOLOGY II: THE AUSTRA LIAN-NEW ZEALAND SECTOR. Antarctic Research Series, 19. American Geophysical Union, Washington, D.C.: 197.209.

COOK, R.J.S., 1966: Some seismological features of the North Macquarie Ridge. Nature, 221:953 954

FALCONER, R.K.H., 1972: The Indian-Antarctic Pacific triple junction. Earth Planet. Sci. Lell., 17: $151-158$

GRIFFIN, B.J., 1982: Igneous and metamorphic petrology of lavas and dykes of the Macquarie Island ophiolite complex. Unpublished Ph.D. thesis, University of Tasmania.

GRIFFIN, B.J. \& VARNE, R., 1980: The Macquarie Island ophiolite complex: mid-Tertiary oceanic lithosphere from a major ocean basin. Chem. Geol., 30: 285 308 .

HAYES, D.E. \& CONOLLY, J.R., 1972: Morphology of the southeast Indian Ocean. In Hayes, D.E. (Ed.): ANTARCTIC OCEANOLOGY II: THE AUSTRALIAN-NEW ZEAIAAN SECTOR Antarctic Research Series, 19. American Geophysical Union, Washington, D.C.: $125 \mathrm{~J} 46$.

HAYES, D.E. \& RINGIS, J., 1973: Sea-floor spreading in the Tasman Sea. Nature, 243:454.458

HAYES, D.E. \& TALWANI, M., 1972: Geophysical investigation of the Macquarie Ridge Complex.
In Hayes, D.E. (Ed.): ANTARCTIC OCEANOLOGY II: THE AUSTRALIAN-NEWZEA LAND SECTOR. Antarctic Research Series, 19. American Geophysical Union, Washington, D.C.: 21$\rceil 234$

HAYES, D.E. TAI.WANI, M. \& CHRISTOFFEL D.E., 1972: The Macquarie Ridge. PROCEED INGS OF THE SCAR/IUGS SYMPOSIUM OF ANTARCTIC GEOLOGY AND SOLII EARTH GEOPHYSICS, OSLO, 1970. Sponsored by the Scientific Committee on Antarctic Research. Universitets Forlaget, Oslo.

HEIRTZLER, J.R., DICKSON, G.O., HERRON, E.M. PITMAN, W.C. III \& LE PICHON, $X$. 1968: Marine magnetic anomalies, geomagnetic fielù reversals and motions of the ocean tloor and continents. J. Geophrs. Res., 73(6) 21192136

HEISKANEN, W.A. \& VENING MEINESZ, F.A. 1958: THE EARTH AND ITS GRAVITY FIELD. McGraw Hill Book Co., Inc.

HOUTZ, R.E.\& MARKL, R.G., 1972: Seismic profiler data between Antarctica and Australia. In Hayes, D.E. (Ed.): ANTARCTIC OCEANOLOGY II THE AUSTRALIAN-NEW ZEALAND SEC $T O R$. Antarctic Research Series, 19. American Geophysical Union, Washington, D.C.: 147164

HOUTZ, R., EWING, J.\& EMBI.Y, R., 1971: Profiler data from the Macquarie Ridge area. In Reid J.L. (Ed.): ANTARCTIC OCEANOLOGY I. Antarctic Research Series, 15: 239245.

IDNURM, M., 1985: Late Mesozoic and Cenozoic palaeomagnetism of Australia I. A redetermined apparent polar wander path. Geophys. $J$ R. Astr. Soc. 83: 399-418

JOHNSON, T. \& MOLNAR, P., 1972: Focal mechanisms and plate tectonics of the south west Pacific. J. Geophys. Res., 77(26): 5000-5032.

JONES, T. \& McCUE, K., 1988: The seismicity and tectonics of the Macquarie Ridge. Pap. Proc. $R$. Soc. Tasm., 122(1): 51.57

KIENI.E, J., 1971: Gravity and magnetic measurements over Bowers Ridge and Shirshov Ridge, Bering Sea. J. Geoph.s. Res., 76(29): 71387153.

I.E.PICHON, X \& HEIRTZLER, J.R., 1968: Magnetic anomalies in the Indian Ocean and sea-floor spreading. 1. Geophis. Re's., 73:2101 2117.

MAWSON, D., 1943: Australian Antarcitic Expedition Sci. Rep., 19/1-19/4. Ser. A(V). Government Printing Office, Sydney, Australia.

MINSTER, J.B.\& JORDAN, T.H., 1978: Present-day plate motions. I. Geophys. Res., 83:5311 5354

MOLNAR, P ATWATER, T MAMMERICKX, J.\& SMITH, S.M., 1975: Magnetic anomalies. bathymetry, and tectonic evolution of the South Pacific since the Late Cretaceous. Geophis. $J$ R. Astron. Soc, 49:383 420.

QUIITY, P.G., RUBENACH, M.\& WII, COXON, J A 1973: Miocene ooze from Macquarie Island. Search, 4(5): $163 \quad 164$ 
RINGIS, I, 1972: The structure and history of the Tasman Sea and the southeast Australian masgin. Unpublished $\mathrm{Ph}$. D. thesis, University of New South Wales.

RUFF, L. \& CAZENAVE, A., 1985: SEASAT geoid anomalies and the Macquarie Ridge Complex. Ph's. Earth Planet. Interiors, 38: 59 69.

RUFF, L., GIVEN, G. \& SANDERS, C., 1982: The tect onics of the Macquarie Ridge, New Zealand: new evidence of strike-slip motion from the earthquake of May 25, 1981, $\mathrm{Mw}=7.7 . E O S$, 63(18): 384

SCHOLZ, C.H., RYNN, J.M.W., WEED, R.W. \& FROHLICH, C., 1973: Detailed seismicity of the Alpine Fault Zone and Fiordland Region, New Zealand. Geol. Soc. Amer. Bull., 84: $3297-3316$

SUMMERHAYES, C.P., 1969: Marine geology of the New Zealand Subantarctic sea-floor. N.Z. Dep. Sci Ind Res. Bull., 190.

SYKES, L., 1967: Mechanism of earthquakes and nature of faulting on the mid-ocean ridges. J. Geophys. Res., 72(8): 2131 2153.

SYKES, L.R., 1970: Seismicity of the Indian Ocean and a possible nascent island between Ceylon and Australia. J. Geophys. Res., 75(26): 5041-5055.

TALWANI, M., HEEZEN, B.C. \& WORZEL, J.L., 1961: Gravity anomalies, physiography and crustal structure of the Mid-Atlantic Ridge. Trav. Sci. Bur. Centr. Seism. UGGI, Int. Ser. A, fasc. 22: 81-111.

TALWANI, M. LE PICHON, X. \& EWING, M., 1965: Crustal structure of mid-ocean ridges, 2. Computed model from gravity and refraction data. J. Geophys. Res., 70:341-352.

TALWANI, M., SUTTON, G.H. \& WORZEL, J.R., 1959: A crustal section across the Puerto Trench. I. Geophys. Res., 64: 1545 1555.

TALWANI, M., WINDISCH, C. \& LANGSETH, M.G. Jr., 1971: Reykjanes ridge crest. A detailed geophysical study. J. Geophys. Res., 76(2): $437-517$

TALWANI, M., WORZEL, J.L. \& LANDISMAN, M., 1959: Rapid gravity computations for twodimensional bodies with application to the Mendocino submarine fracture zone. J. Geophys. Res., 64: 49-59.

TOMODA, Y., 1971: Gravity anomalies in the Pacific Ocean. Paper presented at 12th Pacific Science Congress, Canberra, Australia.

TOMODA, Y., 1973: FREE AIR AND BOUGUER ANOMALIES IN AND AROUND JAPAN. University of Tokyo Press.

VARNE, R., GEE, R.D. \& QUILTY, P.G., 1969: Macquarie lsland and the cause of oceanic linear magnet ic anomalies. Science, 166(3902): 230-232.

VARNE, R. \& RUBENACH, M.J., 1972: Macquarie Island and its relationship to oceanic crust. In Hayes, D.E. (Ed.): ANTARCTIC OCEANOLOGY II: THE AUSTRALIAN-NEWZEA$\angle A N D$ SECTOR. Antarctic Research Series,
19. American Geophysical Union, Washington, D.C.: 251266.

WALCOTT, R.1., 1978: Present tectonics and Late Cenozoic evolution of New Zealand. Geophys. J. R. Astron. Soc., 52:137-164

WATKINS, N.D. \& GUNN, B.M., 1970: Petrology, geochemistry and magnetic properties of some rocks dredged from the Macquarie Ridge. N.Z. J. Geol. Geophys., 14: 153-163.

WEISSEL, J.K., 1972: Analysis of marine magnetic data from south of Australia. Unpublished Ph.D. thesis, University of New South Wales.

WEISSEI, J.K. \& HAYES, D.E., 1971: Asymmetric spreading south of Australia. Nature, 23/(5304): 517521

WEISSEL, J.K. \& HAYES, D.E., 1972: Magnetic anomalies in the southeast Indian Ocean. In Hayes, D.E. (Ed.): ANTARCTIC OCEANOLOGY II: THEAUSTRALIAN-NEWZEA$\angle A N D$ SECTOR. Antarctic Research Series, 19. American Geophysical Union, Washington, D.C.: 165-198.

WEISSEL, J.K HAYES, D.E \& HERRON, E.M. 1977: Plate tectonics synthesis: the displacements between Australia, New Zealand, and Antarctica since the Late Cretaceous. Mar. Geol, 25: 231-277.

WILLIAMSON, P., 1974: The structural evolution of the Macquarie Island region and its relation to ocean crust. Unpublished Ph.D. thesis, University of New South Wales.

WIILIAMSON, P., 1975: Structure of the Macquarie Ridge Complex in relation to the formation and polarity of new and fossil subduction zones. Bull. ASEG., 6: 5455.

WILLIAMSON, P., 1978: The paleomagnetism of outcropping oceanic crust on Macquarie Island. $J$. Geol. Soc. Aust., 25: 387-394

WILLIAMSON, P. \& JOHNSON, B.D., 1974: Crustal structure of the central region of the Macquarie Ridge Complex from gravity studies. Mar. Geophys. Res., II(2): 127-132.

WILliaMSON, P. \& RUBENACH, M.J., 1972: Preliminary report on geophysical studies on Macquarie Island. In Hayes, D. E. (Ed.): ANTARCTIC OCEANOLOGY II: THEAUSTRALIAN-NEW ZEALAND SECTOR. Antarctic Research Series, 19. American Geophysical Union, Washington, D.C.: 234249

WILLIAMSON, P. HAWKINS, L.V.\& LONG, B. 1981: An examination of the possible occurrences of seafloor spreading magnetic anomalies on Macquarie Island. Mar. Geophys. Res., 5: 139155.

WOODWARD, D.J., 1973: Gravity and magnetic anomalies over the Macquarie Ridge. In Fraser, R. (Compiler): OCEANOGRAPHY OF THE SOUTH PACIFIC. N.Z. Nat. Comm. UNESCO, 1972. Wellington.

(accepted 13 January 1988) 